\title{
Tsafon
}

Revue d'études juives du Nord

$72 \mid 2016$

Juifs, Israéliens, dans la littérature française et israélienne

\section{Hanna Yablonka, Les Juifs d'Orient, Israël et la Shoah}

\section{Danielle Delmaire}

\section{(2) OpenEdition \\ Journals}

Édition électronique

URL : https://journals.openedition.org/tsafon/483

DOI : $10.4000 /$ tsafon.483

ISSN : 2609-6420

Éditeur

Association Jean-Marie Delmaire

Édition imprimée

Date de publication : 1 décembre 2016

Pagination : 175-176

ISSN : $1149-6630$

\section{Référence électronique}

Danielle Delmaire, « Hanna Yablonka, Les Juifs d'Orient, Israël et la Shoah », Tsafon [En ligne], 72 | 2016, mis en ligne le 31 mai 2018, consulté le 24 juin 2021. URL : http://journals.openedition.org/tsafon/483 ; DOI : https://doi.org/10.4000/tsafon.483

Ce document a été généré automatiquement le 24 juin 2021.

Tsafon. Revues d'études juives du Nord 


\title{
Hanna Yablonka, Les Juifs d'Orient, Israël et la Shoah
}

\author{
Danielle Delmaire
}

\section{RÉFÉRENCE}

Hanna Yablonka, Les Juifs d'Orient, Israël et la Shoah, traduit de l'hébreu par Avner Lahav, Paris, Calmann-Lévy, Mémorial de la Shoah, 2016, 353 p., 25,90€.

1 Historienne israélienne, spécialiste de l'histoire de la Shoah et enseignante à l'université Ben Gourion, à Beer Sheva (Israël), Hanna Yablonka a fait paraître cet ouvrage en hébreu en 2008 et nous devons à Avner Lahav sa traduction en français, huit ans après cette publication.

2 L'on pourrait résumer le thème de l'étude par cette phrase: le procès des sionistes ashkénazes d'Europe à l'égard de leurs coreligionnaires séfarades des pays méditerranéens et orientaux. La charge de l'auteure est parfois sévère. Selon elle, l'ampleur du désastre de la Shoah a rendu les historiens israéliens de la seconde moitié $\mathrm{du} \mathrm{xx}^{\mathrm{e}}$ siècle insensibles aux persécutions subies par les juifs du monde arabe. Pour mériter une étude scientifique, il fallait être mort à Auschwitz ou dans les pogroms d'Europe. Il en découle une grande méconnaissance du sort des juifs orientaux pendant la guerre. Les programmes scolaires et les ouvrages ont longtemps effacé les exactions commises ailleurs qu'en Europe. Il en fut de même dans les oulpanim, les centres d'accueil où les immigrants nombreux dans les années 1950 à 1980 apprenaient la langue d'Israël et aussi à devenir des citoyens israéliens en s'appropriant l'histoire du peuple juif durant les récentes décennies. Or un grand nombre de ces immigrants étaient originaires des pays arabes. Ce qu'avaient vécu leurs familles passait en arrière fond d'un décor. Les conséquences de l'occupation de la Libye et de la Tunisie par les Italiens puis par les Allemands ne retenaient pas l'attention, ni l'exclusion des juifs d'Algérie par le Gouvernement de Vichy et l'aryanisation de leurs biens. 
3 Les arguments de cette démonstration sont infaillibles et une longue bibliographie pourrait soutenir la thèse. Toutefois, c'est oublier aussi et un peu vite que le martyre des juifs durant la Shoah n'a pas été si facilement reconnu par les Israéliens, les premiers sionistes qui se trouvaient en Palestine durant la guerre. L'intégration des survivants de la Shoah ne s'est pas réalisée aisément : le film L'été d'Aviya (1988) en est une illustration. Au début des années 1950, la petite Aviya subit les moqueries d'autres enfants israéliens, à cause de sa mère rescapée des camps mais au bord de la folie. Le film s'inspirait de faits réels. Ainsi donc, les juifs séfarades victimes de la guerre étaient oubliés mais les juifs ashkénazes rescapés suscitaient moqueries voire mépris. L'auteure l'oublie trop rapidement, hélas !

4 Et il y eut des étapes dans la reconnaissance du martyre de l'ensemble du peuple juif. L'auteure les donne. D'abord par la couverture sur laquelle une photographie montre des Israéliens écoutant un transistor qui transmet les audiences du procès Eichmann. Lors de ce procès (1961), les Israéliens qui se trouvaient en Palestine durant la guerre prirent la dimension du désastre pour le peuple juif: désastre démographique mais aussi et surtout désastre psychologique. Ce fut l'étape ashkénaze : la découverte du drame européen. Puis vint l'étape séfarade : prise de conscience de la mise de côté des juifs orientaux grâce à la révolte de jeunes Israéliens issus de cette immigration, celle des Panthères noires, au début des années 1970 et que l'auteure analyse avec justesse.

5 Le procès des sionistes que $\mathrm{H}$. Yablonka intente est donc imparfait car le chef d'accusation ne concerne pas que les juifs orientaux mais il doit aussi porter sur le refus de voir les souffrances des rescapés des camps.

6 Enfin, le lecteur peine un peu dans sa lecture tant les redondances y sont nombreuses. Au long des 350 pages, il ne cesse d'y lire que le sort des juifs orientaux a été occulté, oublié voire caché dans l'historiographie de la Shoah, par l'opinion publique et le personnel politique d'Israël. L'affaire était entendue dès les premiers chapitres, inutile de le répéter lourdement. Le procédé finit par émousser l'attention, alors que l'auteure voulait éveiller notre conscience sur cet oubli. 